\title{
PENGARUH LATIHAN RESISTANCE DAN PYOMETRIC TERHADAP KEKUATAN OTOT TUNGKAI DAN KELINCAHAN PADA PEMAIN FUTSAL
}

\author{
Riga Mardhika \\ Fakultas Keguruan dan Ilmu Pendidikan, Universitas PGRI Adi Buana Surabaya \\ email: mardhikamail@gmail.com
}

\begin{abstract}
Abstrak
Penelitian ini bertujuan untuk mengetahui: (1) dampak metode latihan plyometric pada peningkatan kekuatan otot tungkai dan klelincahan pemain Futsal; (2) dampak metode latihan resistance terhadap peningkatan kekuatan otot tungkai dan kelincahan pemain Futsal; dan (3) perbedaan pengaruh metode latihan resistance dan plyometric terhadap peningkatan kekuatan otot tungkai dan kelincahan pemain Futsal. Jenis penelitian ini adalah penelitian eksperimen semu dengan menggunakan "Randomized Control Group Pretest-Posttest Design." Subjek penelitian adalah seluruh pemain Futsal putra UKM Unipa Surabaya yang berjumlah 45 atlet. Proses pengambilan data pretest dan posttest dilakukan dengan tes vertical jump dan lari cepat 20 meter. Kemudian hasil data dianalisis dengan cara menggunakan SPSS 19.0 .Berdasarkan uji $t$ dan uji MANOVA yang dilanjutkan dengan uji post-hoc dengan LSD, diperoleh hasil penelitian: (1) Latihan plyometric memberikan pengaruh yang signifikan terhadap tingkat kekuatan otot tungkai dan kelincahan pemain Futsal; (2) Latihan resistance memberi pengaruh yang signifikan terhadap peningkatan kekuatan otot tungkai dan kelincahan pada pemain Futsal; (3) Latihan plyometric memberikan pengaruh yang lebih efektif dari pada latihan resistance terhadap peningkatan power otot tungkai dan kelincahan pada pemain Futsal.
\end{abstract}

Kata Kunci: Latihan Pyometric dan Resistance, power otot tungkai, kelincahan pemain futsal

\section{PENDAhUluan}

Prestasi olahraga tidak dapat diraih dengan cara instan, dibutuhkan bentuk latihan yang sistematis, terukur, terprogram dan teratur dengan mengikutsertakan sport science, teknologi dan ilmu pengetahahuan yang mendukung. Hal ini sejalan dengan pendapat Ambarukmi, dkk (2007: 2) bahwa untuk mencapai suatu prestasi maksimal diperlukan teori latihan yang didukung dengan berbagai ilmu diantaranya biomekanika, gizi olahraga filsafat, psikologi olahraga, anatomi, fisiologi serta keterampilan melatih. Sedangkan menurut pendapat Harsono (1988: 7), prestasi atlet sangat dipengaruhi oleh pendidikan, pengetahuan dan keterampilan individu sebagai pelatih. Pelatih adalah individu yang mempunyai kemampuan keahlian keterampilan untuk membantu atlet atau olahragawan mengeluarkan potensi yang dimiliki menjadi potensi kemampuan yang nyata secara maksimal pada waktu yang relatif singkat (Sukadiyanto dan Muluk, 2011:4).

Kemudian gambar 1.1 di bawah ini merupakan piramida faktor latihan menurut
Bompa yang merupakan hubungan dari keempat faktor tersebut.

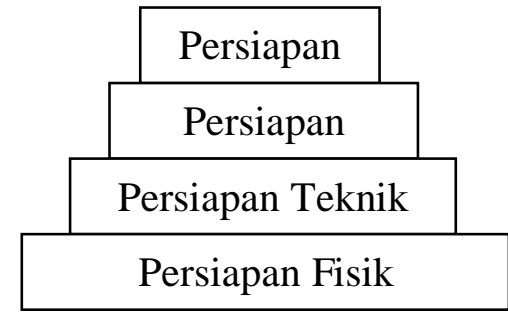

Gambar 1.1 Piramida Faktor Latihan (Bompa, 2009: 61)

Gambar tersebut dapat diartikan persiapan kondisi fisik sebagai landasan untuk meraih prestasi maksimal. Namun, meskipun kondisi fisik lebih utama dibanding dengan yang lain tetapi tidak boleh diabaikan latihan teknik, taktik, maupun mental karena antara satu sama lain mempunyai korelasi dalam meraih prestasi maksimal.

Futsal adalah salah satu cabang olahraga, dimana setiap pemain dan atletnya membutuhkan kondisi fisik yang bagus. Futsal bisa disebut sebagai olahraga yang kompleks. Hal ini disebabkan karena dalam bermain Futsal diperlukan teknik, taktik dan mental khusus. Futsal merupakan salah satu Unit kegiatan Mahasiswa (UKM) di 
Perguruan tinggi yang penyelenggaraannya membutuhkan pembinaan khusus diluar program kurikuler yang dibina oleh pembina/ dan pelatih. Kegiatan ini dilakukan secara terprogram, rutin dan terpantau.

Awal mula dari latihan plyometric adalah metode latihan untuk meningkatkan kecepatan kelincahan dan kekuatan (Chu, 2013: 83). Latihan plyometric merupakan suatu bentuk latihan yang memungkinkan otot bisa mencapai kekuatan maksimal dalam waktu yang sesingkat-singkatnya (Chu, 1998: 2). Latihan plyometric menggabungkan kekuatan dan Kelincahan untuk menghasilkan power yang melibatkan lebih banyak serat otot untuk mengaktifkan spindle otot. Selain itu, sifat elastisitas otot menyebabkan beberapa adaptasi fungsional pada otot, sehingga koordinasi otot menjadi lebih baik dan dapat membuat kekuatan lebih maksimal (Nabizadeh, 2013).

Latihan resistance merupakan bagian integral dari hampir setiap cara latihan atletik dan telah menjadi modus latihan rekreasi yang populer bagi banyak individu aktif secara fisik (Volek 2004: 689). Menurut Bird, Tarpenning dan Marino (2005: 842), latihan resistance dikenal juga sebagai latihan kekuatan atau latihan beban (weight training) yang kerap digunakan sebagai metode latihan yang efektif untuk mengembangkan kebugaran otot. Latihan beban di era sekarang diartikan sebagai bentuk program latihan yang sangat efektif untuk meningkatkan kelincahan, daya tahan, kekuatan (Ahmadi, 2007: 34).

Menurut Mitra, et al (2013: 1) latihan resistance merupakan program latihan yang menyebabkan otot berkontraksi melawan beban eksternal dengan harapan dapat meningkatkan daya tahan, kekuatan, massa otot. Latihan resistance adalah mitra yang ideal untuk latihan plyometric karena membantu mempersiapkan otot-otot untuk pemuatan dampak cepat latihan plyometric. Dalam latihan resistance, atlet bekerja untuk mengembangkan fase eksentrik kontraksi otot dengan terlebih dahulu menurunkan tubuh atau berat badan dan kemudian mengatasi berat menggunakan kontraksi konsentrik (Chu, 2013: 191). Dengan merancang program latihan beban dengan baik, dapat berfungsi untuk meningkatkan kinerja dalam bermain Futsal dengan cara meningkatkan kekuatan, kecepatan, power dan kelincahan, serta dapat mengurangi kemungkinan cedera (Foran,1994: 119).

Berdasarkan permasalahan di atas, pemain Futsal UKM Unipa Surabaya memerlukan program latihan yang bisa meningkatkan power otot tungkai dan kelincahan, dengan harapan dapat meningkatkan prestasi pada pertandingan di tahun berikutnya. Oleh karena itu, akan diadakan penelitian yang berjudul, "Pengaruh Latihan Pyometric dan Resistance terhadap Power Otot Tungkai dan Kelincahan pada Pemain Futsal."

\section{Tujuan Penelitian}

Tujuan penelitian adalah (1) Mengkaji apakah latihan plyometric dapat memberikan pengaruh terhadap peningkatan power otot tungkai dan Kelincahan siswa yang mengikuti UKM Futsal Unipa Surabaya. (2) Mengkaji apakah latihan resistance dapat memberikan pengaruh terhadap peningkatan power otot tungkai dan Kelincahan siswa yang mengikuti UKM Futsal Unipa Surabaya. (3) Mengkaji pengaruh latihan manakah yang lebih efektif dalam meningkatkan power otot tungkai dan kelincahan mahasiswa.

\section{KAJIAN LITERATUR}

\section{Latihan Plyometric}

Menurut Kumar (2013), plyometric merupakan jenis latihan yang dibuat untuk menghasilkan kelincahan, gerakan yang kuat, dan meningkatkan fungsi pada sistem saraf manusia. Pada umumnya, hal ini bertujuan meningkatkan kinerja dalam olahraga tertentu. Latihan plyometric adalah suatu bentuk latihan yang memungkinkan otot dapat mencapai kekuatan maksimal dalam waktu yang cepat. Nama lain plyometric adalah Stretch Shortening Cycle (Chu, 1998: 5). Plyometric adalah teknik latihan yang digunakan oleh atlet yang dapat diamati dan latihan plyometric juga dapat diterapkan pada semua jenis olahraga untuk meningkatkan power, daya ledak yang terukur terkontrol serta aman, efektif dan efisien bagi anakanak maupun remaja. Kontraksi otot sangat kuat yang merupakan respon dari pembebanan dinamik atau rengangan yang cepat dari otot terlibat (Elsayed, 2012: 105).

Nala (1998: 59), mendefinisikan latihan plyometric adalah salah satu usaha yang 
ditujukan dalam mengembangkan daya ledak eksplosif dan kelincahan. Pengembangan ini terkondisi akibat terapat perbaikan pada sistem syaraf pusat serta kekuatan untuk meminimalisir goncangan dan gangguan keseimbangan pada saat bergerak. Sedangkan Radcliffe dan Farentinos (1985: 3-4), mendefinisikan plyometric adalah latihan atau langkah-langkah atau ulangan yang bertujuan menghubungkan gerakan Kelincahan serta power agar dapat memunculkan gerakan yang eksplosif.

\section{Latihan Resistance}

Kekuatan akan dapat tercapai manakala suatu otot diberikan rangsangan secara berulang-ulang untuk menghasilkan suatu tingkat tenaga yang melebihi tenaga yang biasa merangsang otot tersebut. Kekuatan otot tidak dapat terjadi tanpa kontraksi otot yang maksimal. Kontraksi ini dapat terjadi dengan melakukan latihan resistance.

Resistance (perlawanan) merupakan tenaga atau beban yang digunakan oleh anggota tubuh dimana kontraksi otot mencoba untuk mengatasi beban tersebut. Latihan perlawanan ini dapat juga digunakan untuk mengembangkan keuntungankeuntungan dalam kelenturan, Kelincahan dan ketahanan (Uram, 1986: 9).

Bird, Tarpenning dan Marino (2005: 842) menjelaskan bahwa latihan resistance dikenal juga sebagai latihan kekuatan atau latihan beban (weight training) yang kerap digunakan sebagai metode latihan yang efektif untuk mengembangkan kebugaran otot. Latihan resistance memiliki tujuan utama meningkatkan daya tahan dan kekuatan otot. Sependapat dengan hal tersebut, William dan Wilkins (2010: 326) juga mengemukakan hal yang sama, bahwasannya latihan resistance juga dikenal sebagai latihan kekuatan atau latihan beban, yang sekarang ini menjadi bagian standar dari program latihan pribadi. Manfaat dari latihan resistance ini mencakup pada peningkatan kekuatan, massa otot, dan kepadatan tulang.

Menurut Kraemer, et al (2002: 168) latihan resistance dapat meningkatkan kesehatan dan komponen keterampilan kebugaran fisik. Unsure yang terdapat dalam kesehatan diantaranya daya tahan, power otot, fleksibilitas, komposisi tubuh, hipertofi dan kapasitas aerobic. Komponen keterampilan juga termasuk Kelincahan, kelincahan, power, keseimbangan, dan koordinasi. Selain itu, komponen ini berfungsi dasar untuk banyak keterampilan kinerja motor yang diperlukan dalam berbagai olahraga dan kegiatan atletik.

\section{Kelincahan}

Kelincahan (agility) adalah kemampuan individu untuk dapat mengubah posisi tubuh dan arah gerakan dengan cepat dan tepat tanpa kehilangan keseimbangan pada saat bergerak. Kelincahan berkaiatan erat dengan tingkat kecepatan, kelentukan, dan keseimbangan. Tanpa didukung ketiga aspek tersebut, seseorang tidak akan bergerak dengan kelincahan yang baik. Reactive agility training (RAT) merupakan bentuk metode untuk meningkatkan kelincahan.

Menurut Holmberg (2009: 76) reactive agility training (RAT) dapat digunakan sebagai saran untuk melatih atlet dalam membaca dan bereaksi terhadap rangsangan kunci, yang pada akhirnya akan meningkatkan kelincahan. Sheppard (2006: 342) juga berpendapat bahwa reactive agility training (RAT) termasuk melatih antisipasi dan pengambilan keputusan dalam menanggapi pergerakan. Jadi dapat disimpulkan bahwa metode reactive agility training (RAT) tidak hanya untuk meningkatkan kelincahan namun juga dapat meningkatkan antisipasi dan membaca pergerakan sasaran.

Kelincahan adalah salah satu bentuk kemampuan dasar biomotorik yang diperlukan dalam setiap cabang olahraga. Kelincahan adalah kemampuan otot untuk menjawab rangsang dalam waktu sesingkat mungkin (Sukadiyanto dan Muluk, 2011: 116). Sedangkan menurut Sajoto (1988: 58), Kelincahan adalah kemampuan seseorang dalam melakukan gerakan berkesinambungan dan dalam bentuk yang sama, serta dalam waktu yang sesingkat-singkatnya. Kelincahan merupakan laju gerakan otot dalam waktu yang singkat. Hal ini berlaku baik untuk bagian-bagian tubuh (lengan, tangan, dan tungkai) maupun untuk seluruh tubuh berpindah. Kelincahan sangat tergantung dari kekuatan. Tanpa kekuatan, Kelincahan tidak dapat dikembangkan.

Jika seorang siswa atau atlet ingin mengembangkan Kelincahan maksimalnya maka siswa/ atlet juga harus mengembangkan 
kekuatannya. Selain kekuatan berbagai faktor yang dapat mempengaruhi Kelincahan diantaranya yaitu keturunan, umur, masa tubuh elastisitas otot dan jenis otot.

Nossek (1982: 87), Kelincahan adalah kualitas kondisional yang memudahkan seseorang untuk beraksi secara cepat apabila dirangsang untuk melakukan gerakan secepat mungkin. Menurut Nala (1998: 66), Kelincahan merupakan kemampuan untuk merubah posisi atau berpindah dan bergerak dari tubuh atau anggota tubuh dari satu titik ke titik yang lainnya atau bisa berarti mengerjakan suatu aktivitas berulang yang sama serta berkesinambungan dalam waktu yang secepat mungkin.

Kelincahan juga kemampuan untuk melakukan gerakan-gerakan yang sejenis secara berturut-turut dalam durasi cepat dan singkat, atau. kemampuan individu untuk dapat mengubah posisi tubuh dan arah gerakan dengan cepat serta tepat tanpa kehilangan keseimbangan pada waktu bergerak.

\section{METODE PENELITIAN}

Metode penelitian yang digunakan adalah penelitian eksperimen semu. Arikunto (2006: 257) penelitian eksperimen adalah penelitian yang bertujuan untuk mengetahui ada tidaknya suatu akibat dari perlakuan yang diberikan pada subjek selidik.

Berdasarkan metode eksperimen tersebut, maka digunakan rancangan Randomized Control Group PretestPosttest Design.

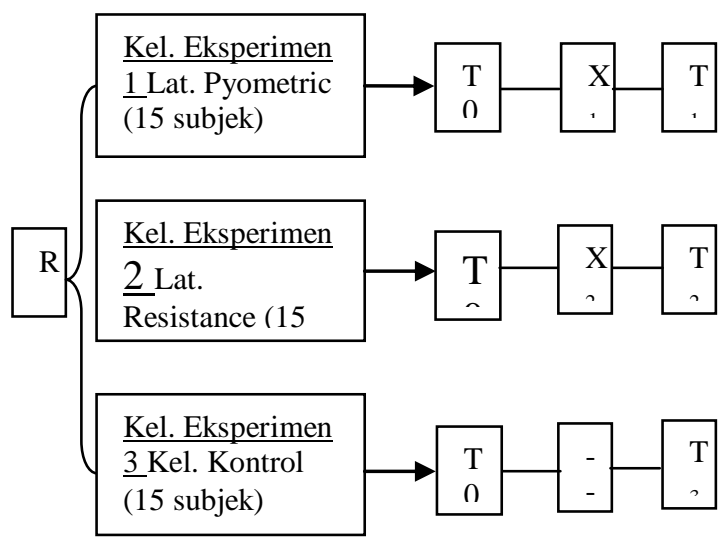

Gambar 2. Rancangan Penelitian

Keterangan:
$\mathrm{R} \quad$ : Random

$\mathrm{T}_{1}$ : Pretest power otot tungkai dan Kelincahan kelompok eksperimen 1

$\mathrm{TO}_{2}$ : Pretest power otot tungkai dan Kelincahan kelompok eksperimen 2

$\mathrm{T}_{3}$ : Pretest power otot tungkai dan Kelincahan kelompok kontrol

$\mathrm{X}_{1}$ : Perlakuan kelompok eksperimen 1, latihan plyometric

$\mathrm{X}_{2}$ : Perlakuan kelompok eksperimen 2, latihan resistance

$\mathrm{T}_{1} \quad$ : Posttest power otot tungkai dan kelincahan kelompok eksperimen 1

$\mathrm{T}_{2}$ : Posttest power otot tungkai dan kelincahan kelompok eksperimen 2

$\mathrm{T}_{3}$ : Posttest power otot tungkai dan kelincahan kelompok control

\section{Populasi dan Sampel}

Populasi merupakan seluruh objek yang menjadi pusat perhatian penelitian, dalam ruang lingkup dan waktu yang ditentukan untuk menjadi target atau sasaran penelitian (Winarno, 2011: 92). Subjek penelitian ini adalah seluruh mahasiswa yang mengikuti kegiatan ekstrakurikuler Futsal di UKM Unipa Surabaya yang berjumlah empat puluh lima orang.

\section{Alat Pengumpulan Data}

Proses menganalisis data dilakukan menggunakan program IBM Statistical Product and Service Solution (SPSS) Statistics 19.0.

Dengan tujuan memberikan makna pada data yang dihasilkan dari tes dan pengukuran akan dilakukan sebagai berikut:

\section{Uji Prasyarat Data}

a. Uji Normalitas Distribusi

Untuk menguji normalitas distribusi data digunakan metode Kolmogorove-Smirnov (Maksum, 2012: 161). Untuk menentukan normal tidaknya distribusi data adalah membandingkan hasil signifikansi perhitungan data dengan taraf signifikansi 5\% atau 0,05. Hal ini berarti, jika pad taraf signifikansi dalam pengujian statistik lebih besar dari 0,05 maka data dinyatakan terdistribusi normal. 
Tabel 1.1 Hasil Uji Normalitas Data Kedua Variabel Terikat

\begin{tabular}{|c|c|c|c|c|c|c|}
\hline \multirow{2}{*}{ Variabel } & \multirow{2}{*}{ Test } & $\begin{array}{c}\text { Kel. } \\
\text { I }\end{array}$ & $\begin{array}{c}\text { Kel. } \\
\text { II }\end{array}$ & $\begin{array}{c}\text { Kel. } \\
\text { III }\end{array}$ & \multirow{2}{*}{ Ket } & Status \\
\cline { 3 - 6 } & Sig & Sig & Sig & & \\
\hline \multirow{2}{*}{$\begin{array}{c}\text { Power otot } \\
\text { tungkai }\end{array}$} & Pretest & 0.200 & 0.200 & 0.200 & $\begin{array}{c}\text { P > } \\
0.05\end{array}$ & Normal \\
\cline { 2 - 6 } & Posttest & 0.200 & 0.200 & 0.200 & $\begin{array}{c}\text { P > } \\
0.05\end{array}$ & Normal \\
\hline \multirow{2}{*}{ Kelincahan } & Pretest & 0.200 & 0.200 & 0.167 & $\begin{array}{c}\text { P > } \\
0.05\end{array}$ & Normal \\
\cline { 2 - 7 } & Posttest & 0.103 & 0.200 & 0.200 & $\begin{array}{c}\text { P > } \\
0.05\end{array}$ & Normal \\
\hline
\end{tabular}

Tabel menunjukkan bahwa perolehan data dari kedua variabel terikat (power otot tungkai dan Kelincahan) adalah berdistribusi normal. Hal ini dikarenakan signifikansi (p) dari masing-masing kelompok menunjukkan (p) atau sig > 0,05 yang mengakibatkan $\mathrm{H}_{0}$ diterima. Jadi didapatkan kesimpulan bahwa data tersebut diambil dari populasi yang berdistribusi normal.

b. Uji Homogenitas

Uji homogenitas varian dilakukan untuk mengetahui homogen atau tidaknya data yang terkumpul. Dalam penelitian ini digunakan Levene's Test yang berarti bila nilai statistik levene's lebih besar dari 0,05 maka data mempunyai varian yang homogen.

Tabel 2.2 Hasil Uji Homogenitas Varians

\begin{tabular}{|c|c|c|c|c|}
\hline Variabel & Test & Sig (P) & Ket & Status \\
\hline \multirow{2}{*}{$\begin{array}{c}\text { Power otot } \\
\text { tungkai }\end{array}$} & Pretest & 0.132 & $\begin{array}{c}\text { P }> \\
0.05\end{array}$ & Homogen \\
\cline { 2 - 5 } & Posttest & 0.197 & $\begin{array}{c}\text { P }> \\
0.05\end{array}$ & Homogen \\
\hline \multirow{3}{*}{ Kelincahan } & Pretest & 0.857 & $\begin{array}{c}\text { P }> \\
0.05\end{array}$ & Homogen \\
\cline { 2 - 5 } & Posttest & 0.798 & $\begin{array}{c}\text { P }> \\
0.05\end{array}$ & Homogen \\
\hline
\end{tabular}

Berdasarkan pada tabel 4.5, dapat dilihat bahwa nilai signifikansi dari masing-masing data variabel terikat (power otot tungkai dan Kelincahan), menunjukkan taraf signifikansi atau (p) > 0,05. Sehingga didapatkan kesimpulan bahwa varians pada setiap kelompok adalah homogen atau sama.

\section{Uji Statistik Hipotesis}

a. Untuk mengetahui perbedaan pengaruh perlakuan pada variabel terikat sebelum dan setelah perlakuan setiap kelompok penelitian paired t-test (uji $\mathrm{t}$ ), dimana tingkat penolakan hipotesis adalah $\alpha=$ 0,05 .

b. Untuk mengetahui besarnya perbedaan pengaruh perlakuan terhadap peningkatan variabel terikat sebelum dan setelah perlakuan antar-kelompok digunakan analisis statistik Multivariate Analysis of Variance (MANOVA).
Untuk mengetahui variabel bebas (independent) mana yang lebih memiliki pengaruh paling besar dalam meningkatan variabel terikat (dependent) digunakan analisis statistik LSD (Least Significant Different) dalam program SPSS seri 19.0, dengan taraf penolakan hipotesis pada $\alpha=$ 0,05 .

Tabel 3.3 Hasil Uji Beda Variabel Dependent pada Kelompok Eksperimen I

\begin{tabular}{|l|c|c|c|c|}
\hline \multicolumn{1}{|c|}{ Variabel } & Pair & t-hitung & $\begin{array}{c}\text { Sig. (2- } \\
\text { tailed) }\end{array}$ & Status \\
\hline Power otot & Posttest - & 7.273 & 0.000 & Berbeda \\
tungkai & Pretest & & & \\
\hline Kelincahan & Posttest - & -7.508 & 0.000 & Berbeda \\
& Pretest & & & \\
\hline
\end{tabular}

Tabel 4.4 Hasil Uji Beda Variabel Dependent pada Kelompok Eksperimen II

\begin{tabular}{|l|c|c|c|c|}
\hline \multicolumn{1}{|c|}{ Variabel } & Pair & t-hitung & $\begin{array}{c}\text { Sig. (2- } \\
\text { tailed) }\end{array}$ & Status \\
\hline Power otot & Posttest - & 5.951 & 0.000 & Berbeda \\
tungkai & Pretest & & & \\
\hline Kelincahan & Posttest - & -5.842 & 0.000 & Berbeda \\
& Pretest & & & \\
& & & & \\
\hline
\end{tabular}

Tabel 5.5 Hasil Uji Beda Variabel Dependent pada Kelompok Kontrol

\begin{tabular}{|l|c|c|c|c|}
\hline \multicolumn{1}{|c|}{ Kariabel } & Pair & t-hitung & $\begin{array}{c}\text { Sig.(2- } \\
\text { tailed) }\end{array}$ & Status \\
\hline Power otot \\
tungkai & Posttest - & 4.506 & 0.000 & Berbeda \\
\hline Kelincahan & $\begin{array}{c}\text { Posttest }- \\
\text { Pretest }\end{array}$ & -3.702 & 0.002 & Berbeda \\
\hline
\end{tabular}

Berdasarkan pada tabel 4.8 diketahui bahwa terdapat perbedaan antara sebelum dengan sesudah treatment untuk setiap variabel dependent (power otot tungkai dan Kelincahan), baik di dalam kelompok

eksperimen I maupun kelompok eksperimen II. Karena nilai $\mathrm{P}<0,05$ maka, dapat disimpulkan bahwa ada perbedaan setelah diberi program latihan plyometric dan resistance. Demikian pada kelompok kontrol juga ada perbedaan, walaupun perbedaanya relatif kecil jika dibandingkan pada kedua kelompok eksperimen. 


\section{Pengolahan dan Analisis Data}

\section{Deskripsi Data Kelompok Eksperimen I (Latihan Plyometric)}

Deskripsi data pada kelompok latihan plyometric ini adalah gambaran mengenai pretest, posttest, rerata dan standar deviasi dari masing-masing variabel terikat yaitu power otot tungkai dan kelincahan.
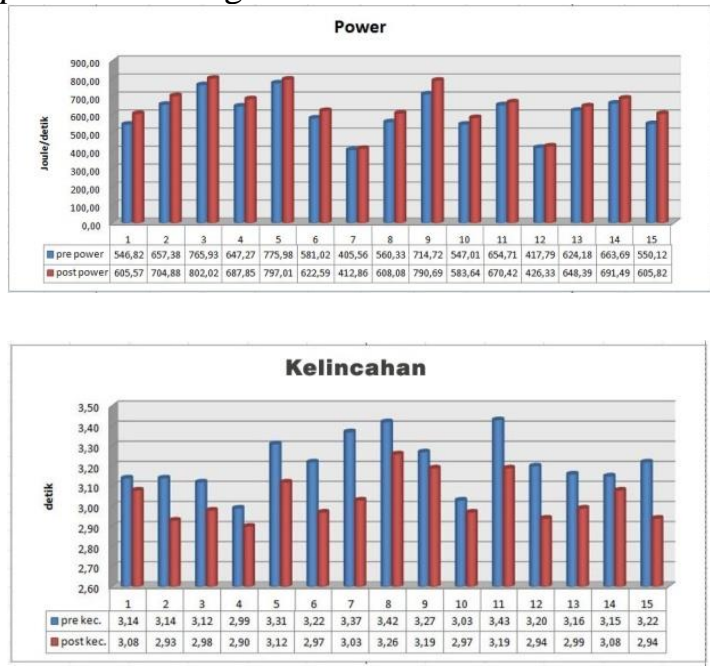

Gambar 3. Pretest dan Posttest dari Kedua Variabel Terikat

Dengan melihat gambar 3 maka dapat disimpulkan bahwa setelah adanya perlakuan latihan plyometric selama delapan minggu dengan frekuensi latihan tiga kali seminggu, dapat memberikan pengaruh yang signifikan terhadap peningkatan power otot tungkai dan Kelincahan.

\section{Deskripsi Data Kelompok Eksperimen \\ II (Latihan Resistance)}

Setelah diberikan perlakuan selama delapan minggu pelatihan dengan frekuensi tiga kali seminggu, terjadi peningkatan pada power otot tungkai dan kelincahan

Tabel 6.6 Perolehan Data sebelum dan sesudah tes Kelompok Eksperimen II

\begin{tabular}{|c|c|c|c|c|c|}
\hline \multirow{2}{*}{ No. } & \multirow{2}{*}{ Nama } & \multicolumn{2}{|c|}{$\begin{array}{c}\text { Power Otot } \\
\text { Tungkai }\end{array}$} & \multicolumn{2}{c|}{ Kelincahan } \\
\cline { 3 - 6 } & & Pretest & Posttest & Pretest & Posttest \\
\hline $\mathbf{1}$ & RP & 528.35 & 530.51 & 3.32 & 3.26 \\
\hline $\mathbf{2}$ & MI & 669.95 & 698.37 & 3.18 & 3.04 \\
\hline $\mathbf{3}$ & SD & 573.57 & 618.45 & 3.26 & 3.21 \\
\hline $\mathbf{4}$ & VR & 543.11 & 577.19 & 3.39 & 3.05 \\
\hline $\mathbf{5}$ & YD & 772.38 & 802.27 & 3.25 & 3.14 \\
\hline $\mathbf{6}$ & OY & 748.85 & 757.23 & 3.07 & 2.97 \\
\hline $\mathbf{7}$ & RA & 621.75 & 665.72 & 3.23 & 3.15 \\
\hline $\mathbf{8}$ & AA & 827.67 & 831.80 & 2.99 & 2.96 \\
\hline
\end{tabular}

\begin{tabular}{|c|c|c|c|c|c|}
\hline $\mathbf{9}$ & FH & 830.12 & 830.85 & 2.95 & 2.92 \\
\hline $\mathbf{1 0}$ & MH & 467.38 & 505.04 & 3.17 & 3.00 \\
\hline $\mathbf{1 1}$ & HA & 765.70 & 788.78 & 3.24 & 3.12 \\
\hline $\mathbf{1 2}$ & KA & 585.62 & 591.02 & 3.49 & 3.35 \\
\hline $\mathbf{1 3}$ & MK & 639.76 & 673.96 & 3.26 & 3.18 \\
\hline $\mathbf{1 4}$ & AAL & 613.78 & 650.48 & 3.31 & 3.17 \\
\hline $\mathbf{1 5}$ & MF & 514.63 & 553.53 & 3.07 & 2.95 \\
\hline \multicolumn{2}{|c|}{ Rerata } & $\mathbf{6 4 6 . 8 4}$ & $\mathbf{6 7 1 . 6 8}$ & $\mathbf{3 . 2 1}$ & $\mathbf{3 . 1 0}$ \\
\hline \multicolumn{2}{|c|}{$\begin{array}{c}\text { Standart } \\
\text { Deviasi }\end{array}$} & $\mathbf{1 . 1 7 2 5 8}$ & $\mathbf{1 . 1 0 2 5 5}$ & $\mathbf{0 . 1 4 6 0 0}$ & $\mathbf{0 . 1 2 6 3 3}$ \\
\hline \multicolumn{2}{|c|}{ Peningkatan } & $\mathbf{3 . 8 4} \%$ & $\mathbf{3 . 5 5} \%$ \\
\hline \multicolumn{7}{|c}{ Berdasarkan } \\
\hline
\end{tabular}

Berdasarkan pada tabel 6, dapat diketahui bahwa nilai rerata pretest power otot tungkai lebih kecil dari pada posttest yaitu sebesar 646.84 dengan 671.68 dan nilai rerata posttest Kelincahan lebih kecil dari pada pretest yaitu sebesar 3.10 dengan 3.21. Dalam hal ini bisa dilihat bahwa terjadi peningkatan $3.84 \%$ power otot tungkai kemudian $3.55 \%$ kelincahan.

\section{Deskripsi Data Kelompok Kontrol}

Deskripsi data pada kelompok kontrol juga merupakan gambaran mengenai pretest, posttest, rerata dan standar deviasi dari masing-masing variabel terikat yaitu power otot tungkai dan kelincahan

Tabel 7.7 Perolehan DataPretest dan Posttest Kelompok Kontrol.

\begin{tabular}{|c|c|c|c|c|c|}
\hline \multirow[t]{2}{*}{ No. } & \multirow[t]{2}{*}{ Nama } & \multicolumn{2}{|c|}{$\begin{array}{c}\text { Power Otot } \\
\text { Tungkai }\end{array}$} & \multicolumn{2}{|c|}{ Kelincahan } \\
\hline & & Pretest & Posttest & Pretest & Posttest \\
\hline 1 & MFR & 480.48 & 490.71 & 3.07 & 3.05 \\
\hline 2 & $\mathrm{ME}$ & 450.20 & 462.81 & 3.34 & 3.27 \\
\hline 3 & MY & 571.10 & 571.86 & 3.15 & 3.16 \\
\hline 4 & $\mathrm{CH}$ & 559.57 & 568.56 & 3.04 & 3.00 \\
\hline 5 & $\mathrm{AH}$ & 583.76 & 587.49 & 3.37 & 3.27 \\
\hline 6 & $\mathrm{BM}$ & 600.15 & 604.61 & 3.31 & 3.31 \\
\hline 7 & $\mathrm{JP}$ & 634.19 & 638.69 & 3.32 & 3.25 \\
\hline 8 & MP & 664.34 & 664.54 & 3.19 & 3.11 \\
\hline 9 & $\mathrm{BR}$ & 643.34 & 645.24 & 3.41 & 3.37 \\
\hline 10 & AS & 705.60 & 707.21 & 3.12 & 3.09 \\
\hline 11 & DD & 569.70 & 582.04 & 2.97 & 2.97 \\
\hline 12 & MP & 626.31 & 626.07 & 3.15 & 3.16 \\
\hline 13 & MA & 706.27 & 710.01 & 3.31 & 3.19 \\
\hline 14 & RS & 620.87 & 627.50 & 3.04 & 3.05 \\
\hline 15 & $\mathrm{AK}$ & 533.97 & 549.09 & 3.22 & 3.14 \\
\hline \multicolumn{2}{|c|}{ Rerata } & 596.66 & 602.43 & 3.20 & 3.16 \\
\hline \multicolumn{2}{|c|}{$\begin{array}{c}\text { Standart } \\
\text { Deviasi }\end{array}$} & 7.33526 & 6.98419 & 0.13735 & 0.11756 \\
\hline \multicolumn{2}{|c|}{ Peningkatan } & \multicolumn{2}{|c|}{$0.97 \%$} & \multicolumn{2}{|c|}{$1.29 \%$} \\
\hline
\end{tabular}

diketahui bahwa nilai rerata pretest power otot tungkai lebih kecil dari pada posttest yaitu sebesar 596.66 dengan 602.43 dan nilai 
rerata posttest Kelincahan lebih kecil dari pada pretest yaitu sebesar 3.16 dengan 3.20. Sehingga terjadi peningkatan $0.97 \%$ untuk power otot tungkai dan $1.29 \%$ untuk kelincahan.

\section{HASIL DAN PEMBAHASAN}

Pengaruh Latihan Plyometric terhadap Peningkatan Power Otot Tungkai dan kelincahan

Menunjukkan terjadinya peningkatan yang signifikan terhadap kekuatan otot tungkai dan kelincahan.

Power otot tungkai dan Kelincahan. Temuan bahwa latihan plyometric dapat meningkatkan power otot tungkai, sejalan dengan pendapat Nabizadeh, et al, (2013: 3798) bahwasannya, latihan plyometric merupakan perpaduan kekuatan dengan kelincahan yang bertujuan menghasilkan power. Sebab itu, latihan plyometric adalah salah satu cara yang perlu dipertimbangkan pelatih untuk memaksimalkan dan meningkatkan daya ledak atlet.

Dari hasil penelitian yang diperoleh dan dukungan dari riset sebelumnya, menunjukkan terjadi peningkatan power otot tungkai dan Kelincahan disebabkan pemberian latihan plyometric. Sehingga kesimpulan yang dapat diperoleh adalah bahwa latihan plyometric berpengaruh signifikan pada peningkatan power otot tungkai dan kelincahan.

Pengaruh Latihan Resistance terhadap Peningkatan Power Otot Tungkai dan Kelincahan

Setelah diberikan latihan resistance selama delapan minggu dengan frekuensi latihan tiga kali per minggu, menunjukkan terjadinya peningkatan yang signifikan terhadap power otot tungkai dan Kelincahan.

Hasil temuan bahwa latihan resistance menyebabkan perubahan peningkatan power otot tungkai, sesuai pada hasil penelitian yang dilakukan oleh Wilson et al. (1933), Wretenberg (1996), Matavulj, et al (2001) dan Ronnestad, et al (2008) dalam Zaerei, et al (2013). Pada latihan berat, peningkatan kekuatan awal tergantung pada dua faktor, yaitu: keterlibatan unit motor yang lebih pada setiap kontraksi dan provokasi impuls saraf yang mengaktifkan unit motor yang lebih pada gilirannya.
Berdasarkan hasil penelitian yang diperoleh, menunjukkan bahwa terdapat peningkatan power otot tungkai dan Kelincahan sebagai akibat pemberian latihan resistance. Sehingga dapat disimpulkan bahwa latihan resistance berpengaruh signifikan terhadap peningkatan power otot tungkai dan kelincahan.

Perbedaan Pengaruh antara Latihan Plyometric dan Resistance terhadap Peningkatan Power Otot Tungkai dan Kelincahan

Untuk mengetahui latihan apa yang lebih efektif dalam meningkatkan power otot tungkai dan Kelincahan, maka dilakukan uji post hoc dengan analisis LSD. Hasil LSD menunjukan bahwa terdapat perbedaan pengaruh yang signifikan terhadap peningkatan power otot tungkai dan Kelincahan.

Berdasarkan pada nilai mean difference pada uji LSD, dapat disimpulkan bahwa kelompok latihan plyometric lebih efektif dalam peningkatan power otot tungkai dan Kelincahan, dibandingkan dengan kelompok latihan resistance maupun kelompok kontrol.

\section{REFERENSI}

Ambarukmi, D.H., Pasurney, P., Sidik, Z.D., Irianto. D.K., Dewanti, R.A., Sunyoto., Sulistiyanto., dan Harapan, M.Y. 2007. Pelatihan Pelatih Fisik Level 1. Jakarta: Kemenegpora.

Arikunto, S. 2006. Prosedur Penelitian Suatu Pendekatan Praktik. Jakarta: PT Rineka Cipta.

Bird, S.P., Tarpenning, K.M., \& Marino, F.E. 2005. Designing Resistance Training Programmes to Enhance Muscular Fitnes a Review of the Acute Programme Variable. Sport Medicine. 35 (10): 841845.

Bompa, T.O. and Haff, G.G. 2009. Periodezation Theory and Methodology of Training. United States. Human Kinetics.

Chu, D.A. 1998. Jumping Into Plyometric (second edition). United State of America: Human Kinetic.

Elsayed, M. dan El, A. M. 2012. Effect of Plyometric Training on Specific Physical Abilities in Long Jump Athletes. World 
Journal of Sport Sciences, 7 (2): 105108.

Harsono. 1988. Coaching dan Aspek-aspek Psikologi dalam Coaching. Jakarta: Dirjen Dikti Proyek Pengembangan Lembaga Pendidikan Tenaga Kependidikan.

Holmberg, P.H. 2009. “Agility Training for Experienced Athletes: A Dynamical Systems Approach". Strength and Conditioning Journal. Vol. 31 No. 3 Oktober 2009. pp. 73-78.

Kreamer W.J., Ratamess, N.A. 2005. Hormonal Responses and Adaptatins to Resistance Exercise and Training. Sports Medicine, 35(4), 339-361.

Kumar, R. 2013. "The Effects Of 6 Week Plyometric Training Program On Agility of Collegiate Soccer Players". International Journal of Behavioral Social and Movement Sciences. Issn:2277-7547. Vol 2. Issue 01.170-176.

Maksum. A. 2012. Metodologi Penelitian dalam Olahraga. Surabaya: Unesa University Press.

Nala, N. 1998. Pelatihan Fisik Olahraga. Denpasar: Universitas Udayana.
Nossek, Y. 1982. General Theory of Training. Lagos: Lagos Institute National Sport. Pan African Press. Terjemahan Teori Umum Latihan (Furqon, M., 1985).

Radcliffe, J.C., and Farentinos, R.C. 1985. Plyometric Explosive Power Training. United State of America: Human Kinetics Publisher Inc.

Sajoto.1988. Pembinaan Kondisi Fisik dalam Olahraga. Jakarta: Depdikbud Dirjen PTPLPTP.

Sheppard, J.M., Young, W.B., Doyle, T.L.A., Sheppard, T.A., and Newton, R.U. 2006. "An Evaluation Of A New Test Of Reactive Agility And Its Relationship To Sprint Speed And Change Of Direction Speed". Journal of Science and Medicine in Sport. Vol. 9, pp. 342-349.

Sukadiyanto dan Muluk, D. 2011. Pengantar Teori dan Metodologi Melatih Fisik. Bandung: Lubuk Agung.

Winarno, M.E. 2006. Dimensi Pembelajaran Pendidikan Jasmani dan Olahraga. Malang: Laboratorium Jurusan Ilmu Keolahragaan. 